\title{
Studies on various potential growth stimulants for growing pigs with particular reference to their activity in supplementing that of copper sulphate
}

\author{
By R. S. BARBER, R. BRAUDE AND K. G. MITCHELL \\ National Institute for Research in Dairying, \\ Shinfield, Reading \\ (Received 26 April 1965-Accepted 26 fuly 1965)
}

The growth-stimulating properties of copper sulphate in the diet of growing pigs are now firmly established; copper supplements are now widely used in commercial pig feeds and are routinely included in all our diets.

The possibility of augmenting the growth-promoting effect of copper by other feed additives was the subject of the trials reported in this paper. Three such materials were investigated, namely, zinc bacitracin (Expt I), Protamone (Expt 2) and Emtryl (Expt 3).

Zinc bacitracin is a narrow-spectrum antibiotic whose mode of action on bacteria is similar in some respects to that of penicillin. Owing to existing regulations zinc bacitracin is at present not available in this country for use as a feed additive. Homb (1959) and Münchberg (1961) obtained significant, although relatively small, improvements in performance of growing pigs with levels of $\mathrm{I} 2$ and $25 \mathrm{~g}$ zinc bacitracin/ton of diet. Holme \& Robinson ( 1963 ), on the other hand, obtained a significant growth response to the addition of $10 \mathrm{~g}$ zinc bacitracin/ton diet with growing pigs in only one of the three experiments carried out.

There is evidence that under some conditions a response may be obtained when $\mathrm{Cu}$ and an antibiotic are given together significantly greater than that obtained from either singly (see Barber, Braude \& Mitchell, 1960). On the other hand, in a largescale co-ordinated trial using copper sulphate and oxytetracycline (Braude, Townsend, Harrington \& Rowell, r 962) no such additive effects were obtained. No comparable work using zinc bacitracin has, however, so far been reported.

Protamone is a thyroidally active iodinated casein produced by Agric-Tech Inc., Kansas City, USA and contains I\% thyroxine activity. Several years ago Barber, Braude \& Mitchell (1954) showed that the addition of $0.3 \mathrm{mg}$ L-thyroxine/lb diet, though having no growth-stimulating effect itself for growing pigs, did appear to enhance the response obtained from either chlortetracycline or penicillin. The object of the experiment now described was to investigate whether there might be a similar effect between thyroxine and $\mathrm{Cu}$.

Emtryl contains $22.5 \%(\mathrm{w} / \mathrm{w})$ 1,2-dimethyl-5-nitroimidazole (dimetridazole) in a diluent of calcium carbonate and calcium phosphate. It is marketed by May and Baker Ltd, Dagenham, for the prevention and treatment of blackhead in turkeys and 
chickens. Lucas ( 1963 ) showed that continuous medication with this compound produced an increase in the live weight of turkeys. Similar results were reported with pigs by Moeller (1964).

\section{EXPERIMENTAL}

For all experiments, enzootic-pneumonia-free Large White pigs in litter-mate groups, balanced as far as possible for sex, were used. The pigs were selected after weaning and were on experiment from approximately 9-10 weeks of age to bacon weight. They were housed in a Danish-type piggery and there was no direct communication between pigs on different treatments. The same basal meal mixtures were given on all experiments and their compositions are shown in Table $x$. The change to the lower-protein meal was made when the live weight of each pig exceeded $x_{9} \mathrm{lb}$ at the weekly weighing. The copper sulphate $\left(\mathrm{CuSO}_{4} \cdot 5 \mathrm{H}_{2} \mathrm{O}\right.$ ) added at $0.1 \%$ (supplying $25^{\circ} \mathrm{ppm} \mathrm{Cu}$ ) was in the form of a finely ground powder. The pigs were fed individually,

Table r. Percentage composition of basal meals received by all pigs on Expts 1,2 and 3

$\begin{array}{lcc} & \begin{array}{c}\text { Up to } 120 \mathrm{lb} \\ \text { live weight }\end{array} & \begin{array}{c}\text { From 120 lb } \\ \text { live weight } \\ \text { to slaughter }\end{array} \\ \text { Barley meal } & 54 & 70 \\ \text { Weatings } & 38 & 25 \\ \text { White-fish meal } & 7 & 3 \\ \text { Steamed bone flour } & - & \text { I } \\ \text { Limestone flour } & \text { I } & \frac{3}{4} \\ \text { Salt } & - & \frac{1}{4} \\ \text { Rovimix }(g / 100 \mathrm{lb}) & 4 \frac{1}{2} & 2 \frac{1}{2}\end{array}$

* Roche Products Ltd, containing 50000 i.u. vitamin $A$ and 12500 i.u. vitamin $D_{3} / g$.

twice daily, with a wet feed ( $3 \mathrm{lb}$ water/lb meal was added just before feeding). In Expts $I$ and 2 the pigs were allowed access to the trough for $30 \mathrm{~min}$ at each feed. The daily allowance of meal for each pig was increased by $0.2 \mathrm{lb}$ every 2 nd day, provided the trough was completely cleared on 2 successive days, up to a maximum of $6 \mathrm{lb} / \mathrm{pig}$ per day. In Expt 3 the pigs were fed to a scale based on live weight, as described by Braude \& Mitchell (195I), again up to a maximum of $6 \mathrm{lb}$ meal/pig per day, adjustments in the meal allowances being made once weekly after weighing. After reaching a minimum live weight of $200 \mathrm{lb}$ at the weekly weighing, the pigs were sent to slaughter the following day and were slaughtered approximately $22 \mathrm{~h}$ after their last feed. Measurements of length and thickness of shoulder and loin back fat at the positions used for commercial grading were taken on all pigs and in addition in Expt 3 a measurement of fat thickness over the eye muscle at the last rib ('fat $\mathrm{K}$ ') was made using an intrascope.

For Expt I (zinc bacitracin) twelve groups each of three litter-mate pigs were used, the three treatments being allocated at random within each group; the details are given in Table 2. The zinc bacitracin product was added at the rate of $0.05 \%$, supplying the equivalent of $8.9 \mathrm{mg}$ zinc bacitracin/lb diet $(20 \mathrm{~g} / \mathrm{ton})$.

In Expt 2 (Protamone), there were twelve pairs of litter-mate pigs, the two treat- 
ments being allocated at random within each pair; the details are given in Table 3 . The Protamone was added at the rate of $44 \mathrm{mg} / \mathrm{lb}$ of diet.

For Expt 3 (Emtryl) eight groups of three litter-mate pigs were used, the three treatments again being allocated at random within each group; the details are given in Table 4. Emtryl was added at I $\mathrm{g} / \mathrm{lb}$ of ration, equivalent to a concentration of $0.05 \%$ dimetridazole.

All three additives were used at levels suggested by the manufacturers.

\section{RESULTS AND DISCUSSION}

Details of the results for Expts I, 2 and 3 are given in Tables 2, 3 and 4 respectively. The only statistically significant treatment differences were in Expt I in which pigs given the ration supplemented with zinc bacitracin (treatment 2) grew significantly more slowly and utilized their food significantly less efficiently than pigs on either of the other two treatments $(P<0.05)$.

Table 2. Mean values with their standard errors for daily weight gain, efficiency of food conversion, dressing percentage, carcass length, and shoulder and loin back-fat thickness of pigs in Expt $\mathbf{1}$

\begin{tabular}{|c|c|c|c|c|c|}
\hline & & Treatment no. & & & \\
\hline & $\begin{array}{c}\text { I } \\
(0.1 \% \\
\text { copper } \\
\text { sulphate) }\end{array}$ & $\begin{array}{c}2 \\
(0.05 \% \text { zinc } \\
\text { bacitracin })\end{array}$ & $\begin{array}{l}{ }^{3} \\
\text { (0.1 \% copper } \\
\text { sulphate plus } \\
0.05 \% \text { zinc } \\
\text { bacitracin) }\end{array}$ & $\begin{array}{l}\text { Standard } \\
\text { error of } \\
\text { means* }\end{array}$ & $\begin{array}{c}\text { Significance } \\
\text { of treatment } \\
\text { mean } \\
\text { square }\end{array}$ \\
\hline No. of pigs & 12 & 12 & 12 & 一 & - \\
\hline Initial weight (lb) & $40 \cdot 3$ & $40 \cdot 6$ & 40.7 & 一 & $\longrightarrow$ \\
\hline Final weight (lb) & $204 \cdot 6$ & 203.4 & $204 \cdot 7$ & - & 一 \\
\hline Days on experiment & $109^{\cdot} \mathbf{I}$ & 116.7 & $109 \cdot 1$ & - & - \\
\hline Daily weight gain (lb) & I.5I & $I \cdot 4 I$ & $I \cdot 5 I$ & 0.026 & $\begin{array}{l}0.05> \\
P>0.01\end{array}$ \\
\hline $\begin{array}{l}\text { Total meal consumed } \\
\text { per pig }(\mathrm{lb})\end{array}$ & $516 \cdot 9$ & $530 \cdot 4$ & $509 \cdot 7$ & 一 & - \\
\hline $\begin{array}{l}\text { Meal consumed/lb live- } \\
\text { weight gain (lb) }\end{array}$ & $3 \cdot 14$ & $3 \cdot 26$ & $3 \cdot$ I I & 0.042 & $\begin{array}{l}0.05> \\
P>0.01\end{array}$ \\
\hline Dressing percentage & $74^{\cdot 2}$ & 73.7 & $74 \cdot 3$ & 0.24 & NS \\
\hline Carcass length (mm) & $785 \cdot 1$ & $791 \cdot 8$ & $788 \cdot 7$ & $4 \cdot 8$ & NS \\
\hline Shoulder fat (mm) & 53.3 & $50 \cdot 4$ & $5 \mathrm{I} \cdot \mathrm{I}$ & I.0 & NS \\
\hline Loin fat $(\mathrm{mm})$ & $32 \cdot 1$ & 30.0 & $29 \cdot 7$ & $I \cdot 2$ & NS \\
\hline
\end{tabular}

The three experiments were planned on the basis that the benefits of $\mathrm{Cu}$ supplementation are now so firmly established that in commercial practice a copper sulphate supplement may be considered a normal constituent of the diet of the growing pig. The potential value of the three supplements investigated was assessed, therefore, by comparing their effects on performance when added to the diet alone or with copper sulphate, with those obtained on a diet supplemented with copper sulphate. Owing to the absence of control pigs given no supplement it is, of course, not possible to assess quantitatively the response to $\mathrm{Cu}$ supplementation, or to any of the three drugs added on their own. 
Table 3. Mean values with their standard errors for daily weight gain, efficiency of food conversion, dressing percentage, carcass length and shoulder and loin back-fat thickness of pigs in Expt 2

Treatment no.

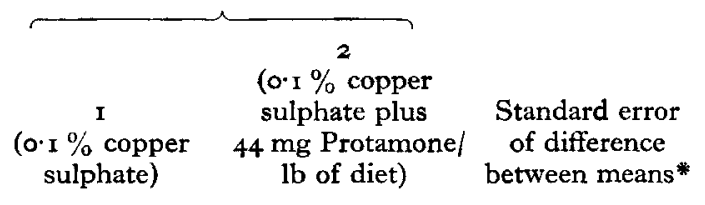

No. of pigs

Initial weight (lb)

Final weight (lb)

Days on experiment

Daily weight gain (lb)

Total meal consumed per

pig (lb)

Meal consumed/lb live-

weight gain (lb)

Dressing percentage

Carcass length (mm)

Shoulder fat (mm)

Loin fat (mm)

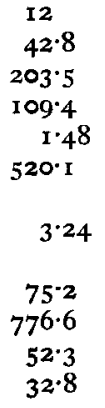

$\begin{array}{cc}12 & - \\ 42.7 & - \\ 205 \cdot 1 & - \\ 109 \cdot 4 & - \\ 1.49 & 0.034 \\ 526 \cdot 1 & - \\ & \\ 3.24 & 0.059 \\ 75.1 & 0.46 \\ 775 \cdot 0 & 7.1 \\ 52.8 & 1.6 \\ 30.8 & 1.5\end{array}$

In no instance was the difference between means significant $(P>0.05)$.

* Based on I I degrees of freedom.

Table 4. Mean values with their standard errors for daily weight gain, efficiency of food conversion, dressing percentage, carcass length, shoulder and loin back-fat thickness, and fat $K$ (see p. 576) measurement with standard errors of pigs in Expt 3

Treatment no.

No. of pigs

Initial weight (lb)

Final weight (lb)

Days on experiment

Daily weight gain (lb)

Total meal consumed per pig (lb)

Meal consumed/lb live-

weight gain (lb)

Dressing percentage

Carcass length ( $\mathrm{mm}$ )

Shoulder fat (mm)

Loin fat (mm)

Fat $\mathrm{K}$ (mm)

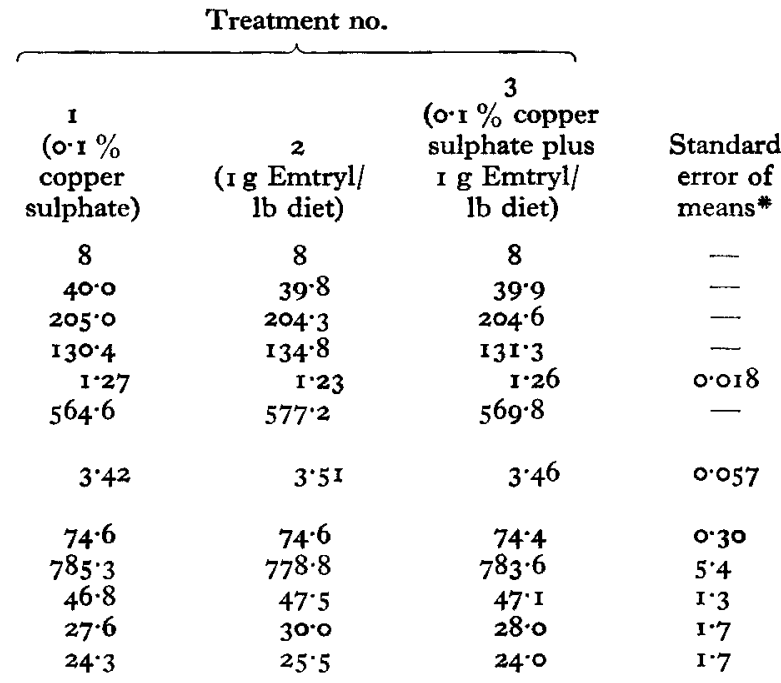

In no instance was the treatment mean square significant $(P>0.05)$.

* Based on I4 degrees of freedom. 
From the results of Expt I, it may be said that the performance of pigs receiving diets supplemented with zinc bacitracin was poorer than that of litter-mates receiving diets supplemented with copper sulphate. Moreover, the performance of the latter could not be enhanced by adding zinc bacitracin. Similar conclusions can be drawn from the results of Expts 2 and 3 regarding the addition of Protamone or Emtryl to a diet supplemented with copper sulphate. However, it is possible that when given on its own Emtryl may have had a growth-stimulating effect similar to that of copper sulphate.

The number of animals involved in these trials was limited and the levels at which the additives were included in the diets were chosen arbitrarily. Often in the past general conclusions on the value of feed additives were drawn from results of single tests similar to those reported in this paper. We are convinced that in the future an objective assessment of the practical value of feed additives can only come from an analysis of results of many such trials carried out under a variety of conditions.

\section{SUMMARY}

I. Results are presented of three experiments involving eighty-four individually fed pigs, covering the growing period between about $40 \mathrm{lb}$ and $205 \mathrm{lb}$ live weight, in which the potential growth-stimulating properties of three different products when added to the diet were studied, particularly in relation to the possibility that they might augment the responses obtained from dietary supplementation with copper sulphate. The three products studied were zinc bacitracin (an antibiotic), Protamone (containing I \% thyroxine activity) and Emtryl (an anti-blackhead drug).

2. None of the three products showed any effect on the performance or carcass quality of the pigs that might suggest they would be either preferable to copper sulphate or of value when added to a diet in addition to the $\mathrm{Cu}$ supplement.

We wish to thank A/S Apothekernes Laboratorium for Specialpraeparater, Oslo, Norway, Agric-Tech Inc., Kansas City, USA and May and Baker Ltd, Dagenham, England, for the gift of the zinc bacitracin, Protamone and Emtryl respectively used in these experiments.

\section{REFERENCES}

Barber, R. S., Braude, R. \& Mitchell, K. G. (1954). Chemy Ind. p. 76.

Barber, R. S., Braude, R. \& Mitchell, K. G. (1960). Br. F. Nutr. 14, 499.

Braude, R. \& Mitchell, K. G. (1951). Agriculture, Lond., 57, 501.

Braude, R., Townsend, M. J., Harrington, G. \& Rowell, J. G. (1962). F. agric. Sci., Camb., 58, 25 I.

Holme, D. W. \& Robinson, K. L. (x963). Anim. Prod. 5, 25 I.

Homb, T. (1959). Norg. LandbrHegsk. Beretn. Fôringsfor, no. 96.

Lucas, J. M. S. (1963). Vet. Rec. 75, 1102.

Moeller, M. W. (1964). F. Anim. Sci, 23, 1216.

Münchberg, F. (196r). In Proceedings of the European Symposium Antibiotics in Animal Nutrition, Oslo, June 196r. Vol. 2, p. 82. Oslo: A/S Apothekernes Laboratorium for Specialpraeparater. 